\title{
Forthcoming evidence-based courses and conferences
}

\section{8}

\section{6-18 April}

3rd International Meeting: Methodological Issues in Oral Health Research Milan, Italy

Further information available at http://events.orikata.it/it/1618aprile2008/Welcome.php

\section{2-3 May}

Evidence-based Dentistry: Champion Conference

Chicago, Illinois, USA

Further information available at www.ada.org/prof/resources/ebd/ conferences_champion.asp

\section{2-16 May}

9th Oxford Course in Evidence-based Dentistry

Oxford, UK

Further information is available at http://cpd.conted.ox.ac.uk/ healthsciences/courses/short_courses/EBD/

\section{June}

1-Day Workshop on Evidence-based Practice

Oxford, UK

Further information is available at www.cebm.net/?o=1018

\section{June-5 July}

Summer School On Modern Methods in Epidemiology and Biostatistics Treviso, Italy

Further information is available at www.biostatepi.org/

\section{1-23 July}

3-Day Workshop on Evidence-based Diagnostics

Oxford, UK

Further information is available at www.cebm.net/?o=1018

\section{8-12 September}

5-Day Workshop on Teaching Evidence-based Practice Oxford, UK

Further information is available at www.cebm.net/?o=1018

\author{
8-12 September \\ 5-Day CASP International Network Training Week \\ Oxford, UK
}

Further information is available at www.cebm.net/index. aspx?o=1137

\section{3-7 October}

16th Cochrane Colloquium

Freiburg, Germany

For further details, see www.cochrane.de/en/colloquium2008.htm

\section{Cochrane Workshops}

Details of workshops organised by the Cochrane Collaboration in a range of locations across the world are listed on the web at www. cochrane.org/news/workshops.shtml

\section{MSc in Evidence for Public Policy and Practice}

Evidence for Policy and Practice Information and Co-ordinating (EPPI) Centre, Social Science Research Unit, Institute of Education, London

This MSc has been designed for graduates and policy-makers, practitioners, managers and researchers who want to become more skilled in systematic reviewing and develop a critical understanding of the relationships between research evidence and public policy and practice.

Students will be encouraged to build their studies around their own areas of interest. These could relate to social welfare, education, crime and justice, transport, health and health promotion, housing, or any other area of social policy or practice.

This degree can be completed in 1 year full-time or over 2 years part-time. Core course modules are delivered in four full-day sessions, 1 week apart. These modules can be taken as short courses without accreditation.

Further information is available at the website eppi.ioe.ac.uk/ cms or contact Cesar Bazan, tel.: +44 (0) 207612 6131; e-mail: eppiadmin@ioe.ac.uk

If you have an evidence-based dentistry event or workshop you would like included on this page please contact us at ebdeditor@ nature.com 